\title{
IMMIGRATION AND REGIONAL COMPETITIVENESS - RELEVANT THEORIES IN THE MIGRATION RESEARCH AND IN THE REGIONAL SCIENCE
}

BEVÁNDORLÁS ÉS REGIONÁLIS VERSENYKÉPESSÉG - A MIGRÁCIÓKUTATÁS ÉS A REGIONÁLIS TUDOMÁNY FŐBB ELMÉLETEINEK ÖSSZEVETÉSE

\author{
Tünde PATAY ${ }^{\mathrm{a}}$ \\ ${ }^{a} \mathrm{PhD}$-candidate, Széchenyi István University, Doctoral School of Regional and Economic Sciences, Györ \\ Hungary - tuende.patay@icloud.com
}

Cite this article: Patay, T. (2018). Immigration and Regional Competitiveness - Relevant Theories in the Migration Research and in the Regional Science. Deturope, 10(1), 71-81.

\begin{abstract}
International and interregional migrations, the geographic form of human mobility have a number of social, economic and political effects. These impacts can vary depending on the reference period, region or sector as well as on the goals and aspects of our interpretation. Another important question in connection with regional competitiveness is how decision makers act and react after perceiving migratory movements. Analysing the interference between immigration and regional development, we can rely on the well-known migration theories, however, a comparison of further models and concepts relating development and regional issues can be more useful for researchers. These questions are relevant, since the issues of the regional science, such as regional competitiveness and regional policy, have in the background strong associations with migratory phenomena.

The aim of this study is to introduce the theoretical background, summarizing the mainstream solutions and the controversies as well. Thus the first part presents the role of the migration theories and these of the regional science in connection with the linkages between immigration and regional competitiveness. Besides it points out the importance of immigrants' inclusion. The next section focuses, complemented with the outcomes of a multivariate statistical analysis, on the theories on determinants and causalities of migration, exploring the connecting points with the issues of the regional policy.
\end{abstract}

Keywords: immigration, regional development, subsidiarity, theories

\begin{abstract}
Absztrakt
A humán migrációt megjelenési formái mellett politikai, gazdasági és társadalmi háttere, a folytonosan alakuló környezet, valamint az ezekből táplálkozó víziók és döntések határozzák meg. A mai térbeli elemzések ugyanakkor kiváltképp a vándorlások irányaira, hatásaira koncentrálnak. A migráció tehát nem csupán aktualitása miatt izgalmas terület. Többféle szempontú és több szinten megközelíthető vizsgálatoknak kínál lehetőségeket, tudományágak és elméletek összetett alkalmazásával.

Ide sorolhatóak a migrációkutatás tételei is. Ezen elméletek egy része a klasszikus alapmodellek rendszerét képezi, többségük azonban az 1980-as évekbeli paradigmaváltást követően alakult ki, illetve formálódik a mai napig.

A tanulmány azt vizsgálja, mennyiben alkalmazhatóak a maga idejükben és tárgykörükben bizonyítást nyert migrációelméletek a bevándorlás hatásainak elemzésekor, különösen a regionális versenyképesség szempontjából. A kérdés megválaszolásában néhány kiválasztott empírikus kutatás ereményeinek értelmezése is segítségünkre van. A migráció okait és körülményeitfeltáró elméletek összevetése, rendszerezése mellett sor kerül az integráció kérdésére, illetve a kapcsolódó kritikus pontok bemutatására is.
\end{abstract}

Kulcsszavak: bevándorlás, elméletrendszer, fejlettség, migráció, régiók 


\section{INTRODUCTION}

Newcomers and foreign residents make significant contributions to development at national or local level: with their workforce, experiences and knowledge, but with their cultural characteristics or international connections as well. On the other side, mobility brings negative effects with: expenditure of the welfare system, conflicts in the society, discrepancies regarding values and goals of the host community, and, of course, deprivation.

Determinants of human migration have an influence of the intensity, direction and other factors of development in the host region, however, these elements and the interference among them correlate a number of further variables as well. The interference between migration and competitiveness should not only be analysed after welfare but the well-being of the local inhabitants as well, however, researches on migratory effects generally focus on certain popular elements (Haas 2007, Hahn 2012), highlighting in most of the cases the fiscal effects and the cultural diversity. A comparative approach to the relevant literature, a good combined dimension of evaluation lead us thus to a multidisciplinary viewpoint.

Although, the factors of local or regional competitiveness vary and are in coherency with one another: labour market issues, urban development, topics of knowledge and education, innovation, crime and security, social segregation, fiscal marginalization, international connections etc. According to Zolberg we should analyse the impacts of immigration from more complete and interdisciplinary aspects on the base of additional theories relating to development, market or historical structures (1989). The aim of this study is to introduce the theoretical background summarizing the mainstream solutions, the role of the migration theories and these of the regional science as well.

\section{OBJECTIVES AND METHODS}

Analysing migratory issues, both the widely-used and the modern migration theories provide us with multidimensional aspects, however, a comparison of the models and the concepts relating development and regional issues are useful as well.

As for the linkages between immigration and regional competitiveness, it is thus essential to explore the role of the migration theories and these of the regional science. Theories of migration, both from classical and modern viewpoint, can help us better understand the migratory factors of local competitiveness, analyse the phenomena from a more complex aspect. However, the critical approach to and application of these theories is essential, since they are often controversial and are partially independent from previous results. 
The paper focuses on the applicability of the migration theories and these of the regional science in connection with the linkages between immigration and competitiveness. It also aims to point out the importance of a controversial topic, the immigrants' inclusion. The study besides tries to explore the role of determinants and circumstances of immigration in the development of the host country or region. This one will be additionally illustrated with a short introduction of the outcomes of a multivariate statistical analysis of migratory and competitive variables.

\section{RESULTS AND DISCUSSION}

\section{Applicability of the basic theories}

Theories to development and regional development are useful for researcher in migratory issues. A comparative approach to the literature of the migration research and the regional science leads us thus to a multidisciplinary viewpoint, similar to a good combined dimension of evaluation.

Three schools of the regional development can particularly help us better understand the interaction between immigration and local development: Keynesian economics, with its governmental interventions and multiplicator effects (Shaw 1989), the exogenous theory on the base of governmental investments and the importance of mobility (Lengyel 2010), and the endogenous growth theory with its local resources and spill-over effect (Ortiguera, Santos 1997).

Table 1 Applicability of the three main theories of the regional science in migration strategies

\begin{tabular}{|c|c|c|c|c|}
\hline Theory & Elements & Period & $\begin{array}{l}\text { Factors } \\
\text { competitiveness }\end{array}$ & $\begin{array}{l}\text { Factors to migration } \\
\text { policy }\end{array}$ \\
\hline Keynes & $\begin{array}{l}\text { Government } \\
\text { expenditure, } \\
\text { quantitative } \\
\text { growth, cumulative } \\
\text { causation }\end{array}$ & $1960-1970$ & $\begin{array}{l}\text { Discrepancies in } \\
\text { regional } \\
\text { development, issues } \\
\text { of income }\end{array}$ & $\begin{array}{l}\text { Regional } \\
\text { discrepancies in } \\
\text { managing migration }\end{array}$ \\
\hline Exogenous & $\begin{array}{l}\text { Basic government } \\
\text { role, mobility of } \\
\text { capitals and } \\
\text { external factors }\end{array}$ & $1970-1990$ & $\begin{array}{l}\text { Employment and } \\
\text { standard of living, } \\
\text { infrastructures }\end{array}$ & $\begin{array}{l}\text { Changes in legal and } \\
\text { administrative } \\
\text { environment, } \\
\text { adaptation in national } \\
\text { policies }\end{array}$ \\
\hline Endogenous & $\begin{array}{l}\text { Bottom-up } \\
\text { movements, local } \\
\text { resources, } \\
\text { integration }\end{array}$ & $\begin{array}{l}\text { from late } \\
1990 \mathrm{~s}\end{array}$ & $\begin{array}{l}\text { Movement } \\
\text { knowledge, human } \\
\text { and social capital, } \\
\text { standard of living }\end{array}$ & $\begin{array}{l}\text { Changes in } \\
\text { compentence levels, } \\
\text { issues of cooperation } \\
\text { and integration }\end{array}$ \\
\hline
\end{tabular}

Source: own edition after Capello (2007) and Lengyel (2010) 
The topic of the effects of temporary and circular migration are basically forgotten theories, though its structure is regulated by the interests of the economies and thus the regional host society is able to react to the changing demand in the labour market (Carrera, HernandezSagrera 2009). The European Union still only calls attention to this issue in its communication first in 2007 (COM 248/2007). On the other hand, Wickramasekara emphasizes, that in case of temporary settlement the integration costs are lower (2011).

\section{The literature on immigrants' inclusion}

The interpretation and determination of social, economic or political integration of a newcomer vary (Angenedt 2000). In the same way, we find in the current political issues but also in the literature - different type of definitions e.g. assimilation, incorporation, integration and inclusion.

Since the 1980s European states have been facing the challenge, how to include immigrants on different stages. Like Fassmann and Münz in their book also present (1996), the illusion of temporary or circular migration has disappeared, guest workers stayed in their new homeland, new migratory groups have been arriving: new labour force, more family members, students, refugees and illegal migrants as well. Marginalisation of migrants could have negative effects on the democratic politics, since it undermines the process of democratic representation and accountability (Jones-Correa 1998). The negative consequences of exclusion could therefore scatter further as social and economic integration, just as the backwash-effect from Myrdal (1960). Thus, national strategies and solutions regarding the integration of immigrants should cover the key areas of growth and well-being: labour market, education, welfare system, civic and political life, and these are only the main points - systematically like by an urban development strategy (Palmai, Patay 2014).

After summarising the areas of inclusion of immigrants, the role of integration can be, however, also derived from the aspect of the theories in connection with democracy, as Fig. 1 shows: One of the basic elements of democracy is that (a) all members of a community have a share in the decision-making processes regarding the future of this community. The second element (b) of a democracy is the equality of opportunity in the social, economic and politic area - these two cases are also defined as main features of the democracy e.g. according to the Democracy Reporting International (2011). Entzinger (1999) adds to this, that another characteristic of modern democracies in the western countries is the respect for cultural differences, identities and values (c). 
Figure 1 The role of inclusion in democracies - from the aspects of the theories

Source: own illustration

\begin{tabular}{|c|c|}
\hline \multicolumn{3}{|c|}{ aspects and tasks of immigrants integration } \\
\hline $\begin{array}{c}\text { a) responsibility for } \\
\text { the mutual future }\end{array}$ & basic aims to integrate \\
\hline
\end{tabular}

The literature approaches to the participation of migrants from different aspects. According to the theory of Morales and Giuni (2011) the meaning inclusion of immigrants can be defined on 4 levels: macro, mezzo, micro level and the level of individual.

Theories privilege the national context, and this is maybe because the range of citizenship and immigration policies is always defined at national level. Regional actors and local governments, however, know the daily life of migrants, strengthening the linkage between migrants and natives (Penninx et al. 2004). Local governments experience first challenges brought by ethnic, cultural and social diversity that immigration causes (Rogers, Tillie 2001). It is also essential to emphasize the civil level, it means, the importance and role of civil organisations. After Koopmans et al. (2005), on the local level civil society organisations open opportunities for migrants, motivating them for collective action. These facts lead us to the statements of the regional sciences especially regarding networks, and social capital (Bourdieu 1978, Loury 2005).

\section{The role of migratory determinants in regional studies}

The European Union also calls our attention to the potential immigration brings with for the development of the European states (European Commission 2015).

At the same time, according to Todaro's hypothesis (1969), immigrants leave their home on the grounds of their - often sketchy - conception on the possibilities. Derived from this and from the theories of Borjas (1989) or Treibel (2011) but also from several empirical studies, groups with less potential on the market (lack of education, experience, possession or contact) tend to migrate to countries or urban areas that can offer a secure welfare background or an equal income distribution, while migrants with higher education, more experiences or possessions usually chose a destination with stronger market competition despite the social inequality in the host country.

Determinants of human migration have an influence of the intensity, direction and other factors of development in the host region, since migrants bring these determinants with (Collins 2013). Thus personal competitiveness of migrants must affect the factors of the regional and nation competitiveness of the host country. It means, migratory determinants and 
the political, fiscal, cultural circumstances of emigration are crucial for the personal and professional development of migrants and therefore for the regional competitiveness as well (e.g. employment or social cohesion).

The theory of Collins can be illustrated on the base of the outcomes of a multivariate statistical analysis, e.g. as Figure 1 shows. This example presents the result of a study that explored how newcomers (from 35 sending countries, from the EU and other macroregions) can contribute in Austria and in addition in Vienna to the development from national, regional or personal aspects. The administrative and legal categories, e.g. the degree of integration, the purpose of stay etc., were defined after the terms of the Austrian Alliens'Law Packet (Peryl, Cayci 2011). The parameters cover the main determinants (economic and political features of the sending countries, female employment etc.), purpose of stay (applied permit, family options etc.) and consequences of settlement (e.g. labour market performance, socioeconomic factors, renewal of permits).

The next figure (Fig. 2) presents in summary the outcomes of this study, as an example to illustrate the linkages between migratory determinants and competitiveness, the role of the circumstances of immigration and of the immigrants themselves in the personal and national/regional competitiveness.

Figure 2 Personal determinants and regional competitiveness the outcomes of a multivariate statistical analysis, derived from indices on the circumstances and effects of immigration in Austria (2013)

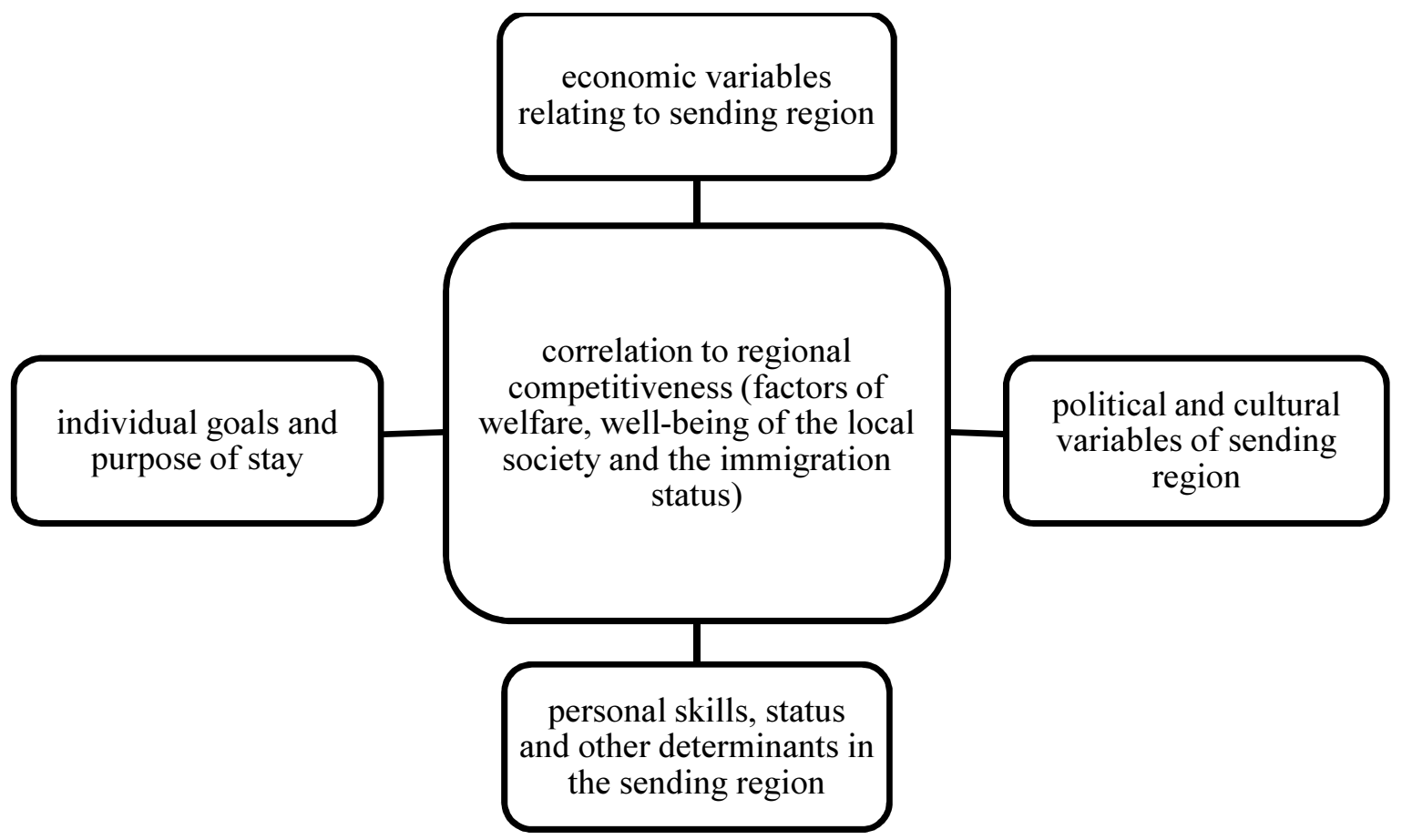

Source: own illustration, the indices of the study were derived from the data of the Austrian Statistical Office, Austrian Ministry of Interior, Statistics of the UN, Austrian Integration Office and Vienna City Government 
A multivariate analysis can thus also indicate the coherency and the linkages between the determinants migrants bring with and the factors of the regional competitiveness, demonstrating this theory of Collins. Migration theories help us thus evaluate the results, understanding the interference between individual and regional competitiveness. It is relevant because a part of the migrants arrives without a detailed plan, they do not gather enough information regarding the future possibilities or hardships they could endure in the host country. However, some migrants aim to stay for a long time, want to work, establish security and take part in the civic life too - while others might only hope to get involved into the social and political system.

\section{The role of the determinants of migration in the literature}

Since the research field of migration is multifaceted, the different areas of migration research and their theories should be analysed from different viewpoints.

Portes identified four different fields: the origins and determinants of migration, the directionality and continuity of the movements, the utilization of the appearance of the mobile labour force and the socio-cultural adaption (1999). The first two research fields, the "old school" paradigms provide us with basic concepts and conclusions regarding motivations and proceeds of migratory movements, such as the behaviourist - and the equilibrium models, and the network concepts. Massey (1993) und later Favell (2008) missed the interdisciplinary approach in migration theories. Castles (2008) and de Haas (2007) also came to similar conclusions highlighting that the literature of the migraton research develops often independently from the previous findings or the evaluations of other disciplines. However, while I agree with these statements, the basic or most quoted migration models and theories can essentially be grouped into four sections: sociology, economics at macro- and micro level, human geography and a group of multidisciplinary approaches (Tab. 2):

Table 2 The main migration theories along disciplines

\begin{tabular}{|c|c|c|c|c|}
\hline Sociology & \multicolumn{2}{|c|}{ Economics } & $\begin{array}{l}\text { Human } \\
\text { geography }\end{array}$ & $\begin{array}{l}\text { Multidisciplinary } \\
\text { aspects }\end{array}$ \\
\hline \multirow[b]{2}{*}{$\begin{array}{l}\text { Social capital } \\
\text { Networks } \\
\text { Pull-push model } \\
\text { Transnationalism }\end{array}$} & Macro- & Micro- & \multirow[b]{2}{*}{$\begin{array}{l}\text { Gravity model } \\
\text { Theory of } \\
\text { transitions } \\
\text { Institute-systems }\end{array}$} & \multirow[b]{2}{*}{$\begin{array}{l}\text { Migrations } \\
\text { systems } \\
\text { Weltsystem } \\
\text { theory } \\
\text { Cumulative } \\
\text { causality }\end{array}$} \\
\hline & $\begin{array}{l}\text { Neoclassics (1) } \\
\text { Keynesians } \\
\text { Dual market } \\
\text { Neo-marxists }\end{array}$ & $\begin{array}{l}\text { Neoclassics (2) } \\
\text { Human capital } \\
\text { New economics }\end{array}$ & & \\
\hline
\end{tabular}

Source: own edition based on Zlotnik (1998) and Kupiszewski (2002) 
Migration theories can be analysed and classified on the base of other aspects as well, thus the particular methods of classification support us in evaluating and applying the different models the literature offers. Theories can be grouped e.g. as basic (classical) and modern ones (Thieme 2003), as optimist (developmentalism) or pessimists (Marxism) theories (de Haas 2008), and furthers, on the base of the reference level such as macro or micro level theories (Morawska 2005). The dominant theories in explaining causes of migration are the follows: the neoclassical theory at macro and at micro level, the dual market, human capital and welt system theories, the push-pull model, the new economics of migration and the model of networks. The migration models derived from different theories of the economics, can be considered both at macro and micro level - with their underlying assumption that migrants move on the base of rational economic considerations and reliable information relating to costs and benefits. In summary, theories of the macro-level can be described - after comparing the mainstream thoughts - as complementary ones, since they only focus on some main factors, leaving other contexts out of consideration such as political background, cultural attitudes, environmental condition or the individual elements of the decisions.

Theories of migration have to account for complex migration systems, according to Arango (2000) or Massey (1999), which encompass the geographical mobility from the time of industrializing, over regimes of transition to mature economies and to anera of globalization and regionalization.

\section{Regional policy and subsidiarity}

The results of the regional science provide us with suggestive aspects regarding regional competitiveness and regional policies in migration research. Global competitiveness motivates provinces and cities to work to attract and retain the creative and talented human capital (Florida 2005).

Immigration policy can thus be designed to direct and manage migration, becoming a serious component of policies developed to react on global competitiveness. Some countries with migratory experiences all have programs to attract the best they want (Gafner, YaleLoehr, 2010). Thus subnational powers are working in various ways to hold their positions as globally attractive and competitive in terms of human resources as well. The roles of municipalities have gained importance in recent years due to the implementation of decentralised policies, though experiences have shown different types of evolution of modernisation in the western and eastern countries (Torma 2003). This modernisation was based on the aspects of fiscal issues, effectiveness and subsidiarity in Western Europe (Balazs 2003). At local level, migration and migration policies have more direct effects. So provide regional or local authorities support in strengthening the linkage between migrants and natives 
(Penninx et al. 2004). Local governments experience first challenges brought by ethnic, cultural and social diversity that immigration causes (Rogers, Tillie 2001).

One of the newly important elements of modern governance is - beyond efficiency - the ability for cooperation (Schedler, Proeller 2000). Matschek and Wirth point out that it is the local level that has been getting more and more tasks over the decades, since in addition to decentralisation; and there is a need for solutions for new fiscal problems, demographical challenges and social conflicts. Here can the regional science provide us with additional aspects. A crucial point in this is the subsidiary approach to the human resources, as Varun Uberoi and Tariq Modood also point out that legal exemption for anti-discrimination practices and multicultural education policies remain mainly in place and not countrywide (2013).

Thus, today, a cooperative attitude of the regional or local government regarding integration of immigrants and the priority of information-transfer among the actors (local community, immigrants, institutions, authorities, entrepreneurs, civil groups, media) profoundly affect the outcomes of the labour market and thus both the social and economic development of the region.

\section{CONCLUSION}

The demographic profile of a region is usually seen as basic background regarding competitiveness and growth. Immigration has, however, not only impacts on the demography, immigrants can contribute significantly to the economic and social development of regions or urban areas.

Thus beyond national legislative, subnational levels also have an important role. The circumstances and effects of the inclusion can be observed in local context as well. It is the local level that directly shapes the attitudes of the native population towards migrants and the immigrants' contribution to the development. The characteristics of the individual level, of the migrants themselves, can also help us to find further solutions for this topic, but the local civil communities have also an impact on the opportunities and willingness of migrants for the participators. Theories of migration, both from classical and modern viewpoint, can help us better understand the migratory factors of local competitiveness, analyse the phenomena from a more complex aspect. However, the critical approach to and application of these theories is essential, since they are often controversial and are partially independent from previous results.

A comparative approach to the relevant literature and a good combined dimension of evaluation lead us thus beyond a simplified interpretation of migratory effects to a multidisciplinary viewpoint. The interference between migratory movements and 
development of subnational units seems to be an interesting but yet largely unexplored topic for researchers and regional policy makers.

\section{REFERENCES}

Balazs, I. (2003). A központi szint alatti közigazgatás helyzete és változásai az EU országokban I-II. Magyar Közigazgatás, 2003/9-10.

Bourdieu, P. (1978). Rekonverziós stratégiák. In Bourdieu, P.: A társadalmi jelenségek újratermelödése. Gondolat, Budapest, 350-378.

Bundesanstalt Statistik Österreich: STATCube - Statistische Datenbank, retrieved am 12.12.2016 from https://www.statistik.at/web_de/services/statcube/index.html

Bundesministerium für Inneres - Republik Österreich: Niederlassung und Aufenthalt Statistiken. Retrieved am 9.12.2016 from http://www.bmi.gv.at/302/Statistik/start.aspx

Bundesministerium für Inneres - Republik Österreich: Asyl - Statistiken. Retrieved am 7.12.2016 from http://www.bmi.gv.at/301/Statistiken/start.aspx

Carrera, S., \&Hernandez Sagrera, R. (2009). The externalisation of the EU's labour immigration policy: Towards mobility or insecurity partnerships. Brussels: CEPS

Democracy Reporting International (2011). Report - International Consensus: Essential Elements of Democracy. Retrieved am 23.8.2017 from http://www.democracyreporting.org/files/essential_elements_of_democracy_2.pdf

Entzinger, H. (1999). Immigrants' political and social participation in the integration process. In: Council of Europe, Directorate of Social and Economic Affairs: Political and social participation of immigrants through consultative bodies. Strasbourg: Council of Europe

European Commission (2015). Policies of DG Migration and Home Affairs. Retrieved am 9.9.2017 from http://ec.europa.eu/dgs/home-affairs/what-we-do/policies/index_en.htm

Eurostat-Data: http://ec.europa.eu/eurostat/statistics-explained/index.php/Main_Page

Fassmann, H., \& Münz, R. (1996). Migration in Europa. Historische Entwicklung, aktuelle Trends, politische Reaktionen. Frankfurt am Main: Campus Verlag

Florida, R. (2005). The Rise of the Creative Class, NY: Basic Books

Hahn, S. (2012). Historische Migrationsforschung. Frankfurt am Main: Campus Verlag

Jones-Correa, M. (1998). Between two nations. Cornell CU

Koopmans, R. (2005). Contested Citizenship. Immigration and Cultural Diversity in Europe. Minnessota: UMP

Lengyel I. (2010). Regionális gazdaságfejlesztés. Versenyképesség, klaszterek és alulról szervezödő stratégiák Budapest: Akadémiai Kiadó

Loury, G. C. (2005). Discrimination in the Post-Civil Rights Era: Beyond Market Interactions. Journal of Economic Perspectives, 12 (2), 117-126.

Morales, L., \& Giuni, M. (2011). Social capital, political participation and migration in Europe. Social Sciences Collection 2011, Hampshire: Palgrave MacMillan

Myrdal, G. (1960). Beyond the Welfare State. Yale University Press.

Ortigueira, S., \& Santos, M. S. (1997). On the Speed of Convergence in Endogenous Growth Models. American Economic Review. 3/87, pp 383-399.

Österreichischer Integrationsfonds (2014). Zahlen und Fakten - Migration und Integration. ÖIF Verlag, Wien

Palmai, E., \& Patay, T. (2014). A területfejlesztes egy uj tipusu megközelitese. In Takacsne György, K. (ed.). Changing, adapting agriculture and countryside. $14^{\text {th }}$ International Scientifi Days. . pp 1213-1221. Gyöngyös: Karoly Robert Föiskola

Pennix, R. et al (2004). Integration of Migrants: economic, social, cultural and political dimensions. European Population Forum 2004. Geneva: UNECE 
Peryrl, J., \& Cayci, V. (2011). Gesetzessammlung: Asyl- und Fremdenrecht - Gesetze und Kommentare, ÖGB Verlag, Wien

Rogers, A., \& Tillie, J. (2001). Multicultural Policies and Modes of Citizenship in European Cities. Aldershot. Ashgate

Schedler, K., \& Proeller, I. (2000). New Public Management. Bern: Verlag Haupt

Shaw, G. K. (ed.) (1989). The Keynesian Heritage Vol. I. Cheltenham: Edward Elgar

Stadt Wien - Magistratsabteilung 23: Statistik, Jahresdaten, Publikationen. Retrieved am 10.10.2016 from https://www.wien.gv.at/statistik/publikationen/index.html

Tillie, J. (2004). Social capital of organisations and their members: explaining the political integration of immigrants in Amsterdam. Journal of Ethnic and Migration Studies. Vol. 30, Issue 3/2004. 529-541.

Torma, A. (2003). Önkormányzati reformok Nyugat-Európában és tanulságaik. Retrieved am 9.8.2017 from www.uni-miskolc.hu/ wwwallin/kozig/hirek/eukozig/onk_reform.pdf

Treibel, A. (2011). Migration in modernen Gesellschaften - Soziale Folgen von Einwanderung, Gastarbeit und Flucht. Juventa Verlag, Weinheim und München

United Nations: Statistics Devision - UNSTATS. Retrieved am 11.12.2016 from www.unstats.un.org

Verba, E. et al. (1995). Voice and Equality. London: Harvard UP

Wickramasekara, P. (2011). Circular Migration: a Triple Win or a Dead End. Discussion Paper 15/2011, London: Global Union Research Network

Zolberg, A. R. (1989). The Next Waves. Migration Theory for a Changing World. International Migration Review, 23/3. 403-430. 